\title{
MEASUREMENT OF SERUM URIC ACID IN GREAT BRITAIN IN 1963
}

BY

\author{
E. G. L. BYWATERS AND V. P. HOLLOWAY \\ Department of Medicine, Post-Graduate Medical School of London
}

Serum uric acid measurement is often an essential step in the diagnosis of gouty arthritis, and its results may form the basis of treatment for prolonged periods. Hyperuricaemia is known of course to occur without gout, either preceding it or arising from some of the other possible causes (Cohen and Bywaters, 1964) which include:

1. Nitrogen retention

2. Increased purine turnover (as in leukaemia) or breakdown

3. The action of drugs such as chlorothiazide or pyrazinamide

4. Starvation, ketosis, or lactacidaemia (as in acute alcoholic excess)

5. Other metabolic faults such as glycogen disease or hypercalcaemia

6. Some unknown reason, when it is called "idiopathic".
Conversely, the level of serum uric acid in gout may be kept within normal limits by uricosuric drugs such as Benemid or salicylates, or more recently, xanthine oxidase inhibitors (Rundles, Wyngaarden, Hitchings, Elion, and Silberman, 1963).

Despite these reservations, the measurement of serum uric acid plays as important a role in studies on gout as does that of glucose in diabetes mellitus; yet in practice the results often conflict with clinical impressions or have been found to lead to a wrong diagnosis. Furthermore, comparisons between one series of observations and another have always been suspect unless they have been performed by the same people using the same methods at the same time, or unless very careful cross checks have been used.

For this reason, and it is to be hoped as a preliminary to putting this important biological para-

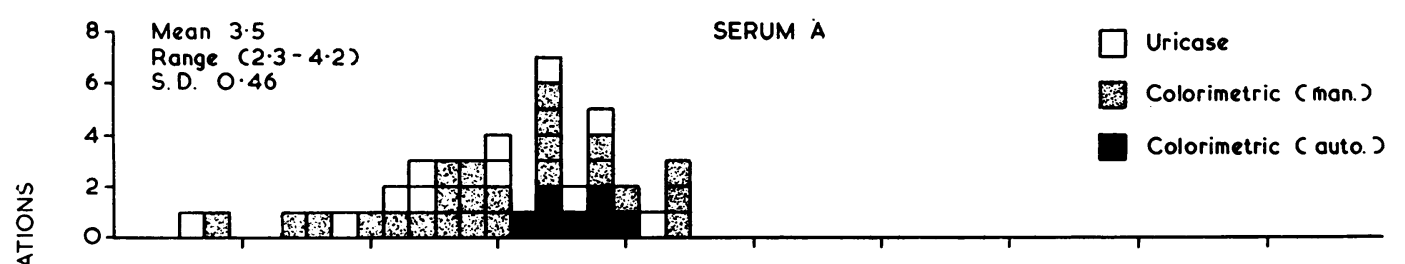

SERUM B
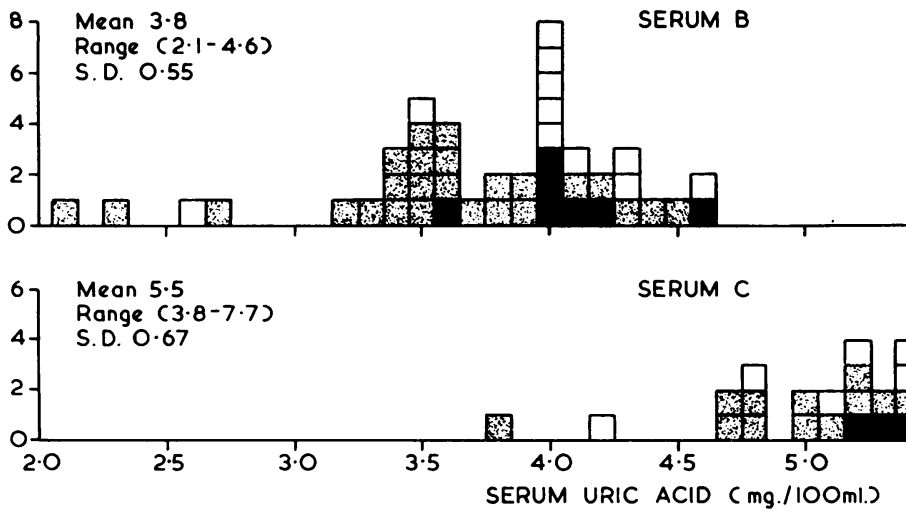

Figure.-Results obtained with Sera A, B, and C. 
meter on a firmer footing, the Empire Rheumatism Council in 1963 initiated a survey of existing practice in Great Britain; it is thought that the data are worth publication if only to underline the very wide variation in results that may be obtained from the same serum in different centres. This was not a "Which"-hunt; there was no "best buy" and no absolute answer which was correct, but the study was conducted on the same principles as those employed by Wootton and King (1953) in investigating laboratory practice.

\section{Methods}

Sera from three donors $(A, B, C)$ were prepared for distribution by Glaxo Research Ltd. After Seitz filtration, the three sera were ampouled and lyophilized in 2 $\mathrm{ml}$. aliquots. One ampoule of each dried serum was sent to each of the 36 centres in Great Britain together with instructions for reconstitution. The centres were asked to return details of the results obtained and method(s) used, as well as what they accepted as the normal range and their reasons for so doing.

TABLE I

COLORIMETRIC (MANUAL)

Total $74(A=24, B=25, C=25)$

\begin{tabular}{|c|c|c|c|c|c|}
\hline \multirow{2}{*}{ Centre } & \multicolumn{2}{|l|}{ Method } & \multicolumn{3}{|c|}{ Serum } \\
\hline & Author & Date & $A$ & $B$ & $C$ \\
\hline $\begin{array}{r}6 \\
13 \\
14 \\
16 \\
20 \\
26 \\
27 \\
30\end{array}$ & Brown & 1945 & $\begin{array}{l}2 \cdot 8 \\
4 \cdot 2 \\
3 \cdot 7 \\
3 \cdot 5 \\
3 \cdot 4 \\
3 \cdot 7 \\
3 \cdot 0 \\
3 \cdot 1\end{array}$ & $\begin{array}{l}3 \cdot 2 \\
4 \cdot 4 \\
3 \cdot 5 \\
3 \cdot 5 \\
3 \cdot 4 \\
3 \cdot 6 \\
2 \cdot 3 \\
3 \cdot 3\end{array}$ & $\begin{array}{l}5.5 \\
6.6 \\
5.5 \\
4.7 \\
6.7 \\
6.0 \\
4.8 \\
4.7\end{array}$ \\
\hline $\begin{array}{r}4 \\
15 \\
28 \\
31 \\
35 \\
\end{array}$ & Folin & 1930 & $\begin{array}{r}3 \cdot 3 \\
3 \cdot 7 \\
4 \cdot 0 \\
4 \cdot 2 \\
-\end{array}$ & $\begin{array}{l}3 \cdot 6 \\
4 \cdot 5 \\
3.9 \\
4 \cdot 3 \\
3 \cdot 8 \\
\end{array}$ & $\begin{array}{l}5 \cdot 0 \\
6 \cdot 0 \\
6 \cdot 4 \\
5 \cdot 7 \\
5 \cdot 1 \\
\end{array}$ \\
\hline $\begin{array}{l}17 \\
19 \\
22\end{array}$ & Caraway & 1955 & $\begin{array}{l}2 \cdot 7 \\
3 \cdot 3 \\
3 \cdot 3\end{array}$ & $\begin{array}{l}2 \cdot 1 \\
3 \cdot 4 \\
3 \cdot 6\end{array}$ & $\begin{array}{l}5 \cdot 3 \\
5 \cdot 2 \\
5 \cdot 2\end{array}$ \\
\hline $\begin{array}{r}2 \\
25\end{array}$ & Henry, Sobel, and Kim & 1957 & $\begin{array}{l}3 \cdot 7 \\
3 \cdot 5\end{array}$ & $\begin{array}{l}3.5 \\
3.9\end{array}$ & $\begin{array}{l}5.4 \\
5.5\end{array}$ \\
\hline $\begin{array}{l}17 \\
33 \\
\end{array}$ & Archibald & 1957 & $\begin{array}{l}3.9 \\
3.2 \\
\end{array}$ & $\begin{array}{l}3 \cdot 7 \\
4 \cdot 2\end{array}$ & $\begin{array}{l}5 \cdot 7 \\
4 \cdot 8\end{array}$ \\
\hline $\begin{array}{r}18 \\
29 \\
\end{array}$ & Bidmead & 1951 & $\begin{array}{l}2.4 \\
3.4\end{array}$ & $\begin{array}{l}2 \cdot 7 \\
3 \cdot 4\end{array}$ & $\begin{array}{l}3 \cdot 8 \\
5 \cdot 0\end{array}$ \\
\hline 1 & Henley & 1957 & 3.9 & $3 \cdot 5$ & $5 \cdot 8$ \\
\hline 5 & $\begin{array}{l}\text { Eichhorn, Zelmanow- } \\
\text { ski, Lew, Rutenberg, } \\
\text { and Fanias }\end{array}$ & $\overline{1961}$ & $4 \cdot 2$ & $3 \cdot 8$ & $7 \cdot 7$ \\
\hline 7 & Kern and Stransky & 1937 & $3 \cdot 4$ & $4 \cdot 1$ & $5 \cdot 5$ \\
\hline \multicolumn{3}{|l|}{$\begin{array}{l}\text { Mean } \\
\text { Range } \\
\text { S.D. }\end{array}$} & \begin{tabular}{|c|}
$3 \cdot 5$ \\
$2 \cdot 4-4 \cdot 2$ \\
$0 \cdot 49$
\end{tabular} & $\begin{array}{r}3 \cdot 6 \\
2 \cdot 1-4 \cdot 5 \\
0.58\end{array}$ & $\begin{array}{c}5 \cdot 5 \\
3 \cdot 8-7 \cdot 7 \\
0 \cdot 95\end{array}$ \\
\hline
\end{tabular}

\section{Results}

Replies were received from all the participating centres and since some used more than one method, 42 results were obtained for Serum A and 43 results for Sera B and C. The fifteen methods used fell into three main groups: colorimetric (manual), colorimetric (autoanalyser), and ultra-violet spectrophotometric (uricase). It will be seen that there is a very wide scatter (Figure, opposite); this is least for the autoanalyser results.

The results in each group are summarized in Tables I, II, and III.

\section{(a) Methods}

\section{Comment}

(1) Colorimetric Method.-The basic demands of any quantitative estimation are specificity, quantitative recovery, and reproducibility. No colorimetric

TABLE II

COLORIMETRIC (AUTOANALYSER)

Total 21

\begin{tabular}{|c|c|c|c|c|c|}
\hline \multirow{2}{*}{ Centre } & \multicolumn{2}{|c|}{ Method } & \multicolumn{3}{|c|}{ Serum } \\
\hline & Author & Date & $A$ & $B$ & $C$ \\
\hline $\begin{array}{r}8 \\
10 \\
21 \\
31 \\
32\end{array}$ & $\begin{array}{l}* \text { Folin } \\
* \\
* \\
*\end{array}$ & 1930 & $\begin{array}{l}3 \cdot 9 \\
3 \cdot 9 \\
3 \cdot 7 \\
3 \cdot 8 \\
3 \cdot 7\end{array}$ & $\begin{array}{l}4 \cdot 0 \\
4 \cdot 2 \\
4 \cdot 1 \\
4 \cdot 0 \\
4 \cdot 0\end{array}$ & $\begin{array}{l}5 \cdot 3 \\
6 \cdot 1 \\
5 \cdot 5 \\
5 \cdot 4 \\
6 \cdot 0\end{array}$ \\
\hline 12 & * Brown & 1945 & $4 \cdot 0$ & $4 \cdot 6$ & $5 \cdot 6$ \\
\hline 11 & * Caraway & 1955 & $3 \cdot 6$ & $3 \cdot 6$ & $5 \cdot 2$ \\
\hline $\begin{array}{l}\text { Mean } \\
\text { Range } \\
\text { S.D. }\end{array}$ & & & $\begin{array}{c}3 \cdot 8 \\
3 \cdot 6-4 \cdot 0 \\
0 \cdot 15\end{array}$ & $\begin{array}{c}4 \cdot 1 \\
3 \cdot 6-4 \cdot 6 \\
0 \cdot 31\end{array}$ & $\begin{array}{c}5 \cdot 6 \\
5 \cdot 2-6 \cdot 1 \\
0 \cdot 32\end{array}$ \\
\hline
\end{tabular}

* Modified for use with the Autoanalyser.

TABLE III

URICASE

Total 33

\begin{tabular}{|c|c|c|c|c|c|}
\hline \multirow{2}{*}{ Centre } & \multicolumn{2}{|l|}{ Method } & \multicolumn{3}{|c|}{ Serum } \\
\hline & Author & Date & $A$ & $B$ & $C$ \\
\hline $\begin{array}{r}1 \\
3 \\
7 \\
17 \\
23\end{array}$ & $\begin{array}{l}\text { Praetorius and } \\
\text { Poulsen } \\
\text { Gjørup, Poulsen, } \\
\text { and Praetorius }\end{array}$ & $\begin{array}{l}1953 \\
1955\end{array}$ & $\begin{array}{l}3 \cdot 9 \\
3 \cdot 5 \\
3 \cdot 2 \\
3 \cdot 5\end{array}$ & $\begin{array}{l}3 \cdot 5 \\
4 \cdot 6 \\
4 \cdot 0 \\
4 \cdot 0\end{array}$ & $\begin{array}{l}5 \cdot 4 \\
4 \cdot 2 \\
5 \cdot 6 \\
5 \cdot 9\end{array}$ \\
\hline $\begin{array}{l}24 \\
28 \\
36 \\
\end{array}$ & & & $\begin{array}{l}3 \cdot 8 \\
3 \cdot 2 \\
2 \cdot 3 \\
3 \cdot 7\end{array}$ & $\begin{array}{l}4 \cdot 0 \\
4 \cdot 0 \\
2 \cdot 6 \\
4 \cdot 3\end{array}$ & $\begin{array}{l}5 \cdot 4 \\
5 \cdot 6 \\
4 \cdot 8 \\
5 \cdot 7\end{array}$ \\
\hline 34 & $\begin{array}{l}\text { Liddle, Seegmil- } \\
\text { ler, and Laster }\end{array}$ & 1959 & $3 \cdot 1$ & $4 \cdot 0$ & $5 \cdot 2$ \\
\hline $\begin{array}{r}9 \\
14 \\
\end{array}$ & $\begin{array}{l}\text { Feichtmeir and } \\
\text { Wrenn }\end{array}$ & 1955 & $\begin{array}{r}2 \cdot 9 \\
4 \cdot 1 \\
\end{array}$ & $\begin{array}{l}4 \cdot 3 \\
4 \cdot 1 \\
\end{array}$ & $\begin{array}{l}6 \cdot 0 \\
5 \cdot 1 \\
\end{array}$ \\
\hline $\begin{array}{l}\text { Mean } \\
\text { Range } \\
\text { S.D. }\end{array}$ & & & $\begin{array}{c}3 \cdot 4 \\
2 \cdot 3-4 \cdot 1 \\
0 \cdot 53\end{array}$ & $\begin{array}{c}4 \cdot 0 \\
2 \cdot 6-4 \cdot 6 \\
0.53\end{array}$ & $\begin{array}{c}5 \cdot 4 \\
4 \cdot 2-6 \cdot 0 \\
0 \cdot 53\end{array}$ \\
\hline
\end{tabular}


method for the estimation of serum uric acid completely satisfies these criteria. Among sources of error, co-precipitation of uric acid with proteins, and non-specific reduction, tend to be compensatory, and provided that the greatest care is taken to ensure standard conditions of $\mathrm{pH}$, temperature, and time of reaction, reproducible results approximating the values obtained by uricase spectrophotometric method may be obtained.

Results from nine colorimetric (manual) methods were reported in the survey, the most popular being those of Brown (1945; eight centres) and Folin (1930: five centres). There was no evidence that any method was markedly superior or inferior. It was somewhat surprising to note that only two centres used the Archibald (1957) modification of Kern and Stransky (1937), for this is a simple technique which gives total recovery of uric acid and uses nonpoisonous reagents which are relatively stable. Some workers have found that the polyanethol sodium sulphonate available in Great Britain does not prevent the formation of gels and precipitates, but if 30 per cent. (w/v) urea is used in place of this reagent, the final solutions remain free from turbidity. Haemolysed sera or plasma should not be used, since ergothionine, glutathionone, and other cellular constituents give non-specific reduction in these colorimetric methods.

Use of the autoanalyser with colorimetric methods should eliminate some sources of error, since dialysis is used in place of protein precipitation, and temperature and time of reaction are kept constant. This survey confirms this opinion, for the results obtained by the autoanalyser, particularly where used with a modified Folin method, show the greatest precision and reproducibility between centres. Mean values slightly greater than those obtained by the other groups would be expected, since loss of uric acid during protein precipitation is avoided, but some non-specific reduction may occur.

(2) Ultra-violet Spectrophotometric (Uricase) Method.-Differential ultra-violet spectrophotometric methods, using purified uricase, give a high degree of precision, but only when carried out under critically standardized conditions. They are, however, thus made time-consuming and attempts to streamline the technique give less satisfactory results. The survey revealed that results obtained by these methods showed a scatter as great as that by the colorimetric (manual) methods and greater than that obtained by the autoanalyser technique.

For uricase techniques, sera should be separated aseptically and stored at $-20^{\circ} \mathrm{C}$. if immediate analysis is impossible. Stocks of sera for quality control should be stored in small aliquots to prevent contamination through repeated sampling.

\section{(b) Effects of Seitz Filtration and Freeze-Drying}

The results obtained on all three samples were somewhat lower than had been expected from previous examination and a further experiment showed that slight losses, of about 10 per cent., occurred during Seitz filtration (presumably through adsorption on to the filter) and during lyophilization, and that these were additive.

\section{(c) Normal Values}

The majority of the centres taking part in the survey had not derived their own normal ranges for the method or methods employed and, in general, used published figures which had often been obtained by the use of a different method. Some failed to recognize the normal difference between male and female values or to differentiate between pre- and post-menopausal women.

\section{Conclusions}

(1) The method of choice for the routine estimation of large numbers of sera would appear to be that of Folin (1930) modified for use with the autoanalyser.

(2) The uricase technique of Praetorius and Poulsen (1953) and Gjørup, Poulsen, and Praetorius (1955) should be used for special projects where absolute uric acid values are required.

(3) All uric acid estimations should be carried out under critically standardized conditions with the routine incorporation of quality control and recovery experiments.

(4) The normal ranges for men and for pre- and post-menopausal women, by the method routinely employed in the laboratory, should be determined.

(5) Details of quality control, recoveries, and normal ranges should be included in all publications to facilitate the comparison of results.

This study was initiated under the aegis of the Empire Rheumatism Council Research Sub-committee, and the participants included most of the main hospital centres in Great Britain and particularly those known to be interested in uric acid measurements.

We are most grateful to Prof. I. D. P. Wootton for advice, and to Dr. P. Muggleton, of Glaxo Research Ltd., who kindly arranged for the ampouling and lyophilization of the sera, which were sent out by the Empire Rheumatism Council. Our thanks are also due to the pathologists and biochemists of the participating centres for their cooperation. 


\section{REFERENCES}

Archibald, R. M. (1957). Clin. Chem., 3, 102.

Bidmead, D. S. (1951). J. clin. Path., 4, 370.

Brown, H. (1945). J. biol. Chem., 158, 601.

Caraway, W. T. (1955). Amer.J. clin. Path., 25, 840.

Cohen, H., and Bywaters, E. G. L. (1964). "Gout and Other Metabolic Disorders producing Joint Disease", in "Textbook of the Rheumatic Diseases", ed. W. S. C. Copeman, 3rd ed. Livingstone, Edinburgh.

Eichhorn, F., Zelmanowski, S., Lew, E., Rutenberg, A., and Fanias, B. (1961). J. clin. Path., 14, 450.

Feichtmeir, T. V., and Wrenn, H. T. (1955). Amer. J. clin. Path., $25,833$.

Folin, O. (1930). J.biol. Chem., 86, 179.

Gjørup, S., Poulsen, H., and Praetorius, E. (1955). Scand. J. Lab. clin. Invest., 7, 201.

Henley, A. A. (1957). Ass. clin. Biochem. News Letter, $15,19$.

Henry, R. J., Sobel, C., and Kim, J. (1957). Amer. J. clin. Path., 28, 152.

Kern, A., and Stransky, E. (1937). Biochem. Z., 290, 419.

Liddle, L., Seegmiller, J. E., and Laster, L. (1959). J. Lab. clin. Med., 54, 903.

Praetorius, E., and Poulsen, H. (1953). Scand. J. Lab. clin. Invest., 5, 273.

Rundles, R. W., Wyngaarden, J. B., Hitchings, G. H., Elion, G. B., and Silberman, H. R. (1963). Trans. Ass. Amer. Physcns, 76, 126.

Wootton, I. D. P., and King, E. J. (1953). Lancet, 1, 470.

\section{Détermination de l'acide urique dans le sérum en Grande Bretagne en 1963}

\section{RÉSUMÉ}

(1) La méthode de choix pour titrer régulièrement un grand nombre de sérums semble être celle de Folin (1930) modifiée pour l'emploi avec l'autoanaliseur.
(2) Le procédé à l'uricase de Praetorius (1953, 1955) doit être reservé pour des projets spéciaux, lorsqu'on a besoin de valeurs absolues d'acide urique.

(3) Toutes les déterminations de l'acide urique doivent être effectuées en conditions critiques standard, incorporant un contrôle régulier qualitatif et des expériences de récupération.

(4) On doit déterminer les limites normales pour les hommes, et pour les femmes avant et après la menopause, par des méthodes habituelles du laboratoire.

(5) Des particularités concernant le contrôle qualitatif, la récupération et les limites normales doivent être mentionnées dans tous les travaux publiés pour faciliter la comparaison des résultats.

\section{Determinación del ácido úrico en el suero en Gran Bretagna en 1963}

\section{SUMARIO}

(1) El método de elección para estimar regularmente un gran número de sueros parece ser él de Folin (1930), modificado para el uso con un autoanalizador.

(2) El procedimiento a uricasa de Praetorius (1953, 1955) debe emplearse en proyectos especiales, cuando se necesita valores absolutos de ácido úrico.

(3) Todas las determinaciones del ácido úrico deben ser llevados a cabo en condiciones standard críticas, incorporando la verificación calitativa regular y experimentos de recobro.

(4) Se deben determinar los limites normales para hombres y para mujeres antes y después de la menopausia por métodos habituales del laboratorio.

(5) Datos particulares respecto a la verificación calitativa, el recobro y los límites normales deben figurar en los trabajos publicados para facilitar la comparación de los resultados. 